\title{
A MATURITY MODEL FOR C2C SOCIAL COMMERCE BUSINESS MODEL
}

\author{
Supattana Sukrat \\ King Mongkut's University of Technology Thonburi \\ supattana.s@psu.ac.th \\ Borworn Papasratorn \\ King Mongkut's University of Technology Thonburi \\ borworn@sit.kmutt.ac.th
}

\begin{abstract}
Individuals and sole proprietors in developing countries like Thailand have been reaping the financial benefits of social media technologies that have created new trading channels. Commercial activities conducted by users of social networking sites among users have grown significantly. A proliferation of new vendors has forced existing ones to improve their business for competitive advantage. Systematic and effective implementation and improvement have taken place thanks to tools like the maturity model that allow for business capability self-assessment. Although several studies describe the maturity of social media usage in organizations or businesses, few of them focus on the $\mathrm{C} 2 \mathrm{C}$ business model. This study presents a maturity model of $\mathrm{C} 2 \mathrm{C} \mathrm{s}$-commerce for assessing stage of growth of $\mathrm{C} 2 \mathrm{C}$ s-commerce. The methodology included both secondary and case study research. The model consists of five maturity levels (ad hoc, active repeatable, proactive functional, pre-emptive managed, and optimized). Their characteristics have been researched through four dimensions (business environment, people, process, and technology). The proposed maturity model helps online vendors conduct business activities by reducing business risks while supporting consumers by the minimizing risks associated with purchasing.
\end{abstract}

Keywords: Social Commerce, Maturity Model, Consumer-to-Consumer, C2C s-Commerce

\section{INTRODUCTION}

The advancement of social media technologies has created a new form of online business called Consumer-to-Consumer social commerce (C2C 
s-commerce) ${ }^{1}$. Consumers leverage the features and functionalities of social networking sites (SNS) to facilitate commercial activities among other users. Consumers exchange products and services ${ }^{1}$ on sites like Facebook, Line, Instagram, Twitter, and Pinterest. For example, Facebook subscribers (vendors) use a personal profile for product presentation and Line chat for interaction with their customers (e.g., placing an order, product and delivery confirmation).

C2C s-commerce business model is expected to grow significantly in the future due to an increase in the number of s-commerce users worldwide ${ }^{2}$, especially in developing countries ${ }^{3}$. The monetary value of the $\mathrm{C} 2 \mathrm{C}$ s-commerce market in Thailand is expected to hit US\$510 million per year ${ }^{4}$. Conversely, B2C e-commerce in developing countries such as Thailand is not widespread among consumers. The monetary value of the $\mathrm{B} 2 \mathrm{C}$ e-commerce market is significantly lower than the values of the $\mathrm{B} 2 \mathrm{C}$ e-commerce in the developed world ${ }^{5}$. To conclude, people in developing countries are likely to conduct commercial activities through SNS more than e-commerce websites. Therefore, having a tool for understanding the patterns of business growth and for capability assessment and business improvement such as maturity model can reduce business risks in $\mathrm{C} 2 \mathrm{C}$ s-commerce because a maturity model has been developed for explaining an organization's capabilities or process performance aspects spanning consideration from initial to mature stage ${ }^{6}$.

Several maturity models have been proposed in different fields to assess a process performance for improvement. The Capability Maturity Model (CMM), proposed by Paulk et al. $^{7}$ is one of the best known frameworks in software engineering. It is used for software process assessment and performance improvement. In terms of IT process management and control, COBIT's maturity model plays a critical role in understanding how well an organization's deployed management processes $\operatorname{are}^{8}$. In the business domain, Lee, Lee, and Kang ${ }^{9}$ proposed the business process maturity model (BPMM) for the measurement and improvement of business process competence. Mendes, Leal, and Thomé ${ }^{10}$ offered a maturity model for supply chain management. The model allows an organization to assess its capabilities when developing business strategies to become a demand-driven company. Oliva ${ }^{11}$ presented a maturity model for enterprise risk management in the supply chain of large companies. With the internet and associated technologies, a new form of internet-based application in organizational processes has changed the organizational environment from traditional to computer-based companies. Maturity models of an electronic organization have emerged such as e-learning ${ }^{12}$, e-government ${ }^{13}$, e-business ${ }^{14}$, and e-commerce ${ }^{15,16}$. Social media technology 
provides new opportunities for competitive advantage for both traditional and online businesses. It therefore comes as no surprise that researchers are now offering maturity models for social media adoption and management ${ }^{17}$, $18,19,20,21$.

The literature describes few maturity models that focused on social commerce. This paper provides a maturity model of $\mathrm{C} 2 \mathrm{C}$ s-commerce for analyzing a vendor's business implementation capability in an s-commerce environment by combining the results from the review of the maturity models in related domains and using a case study approach. The model may help vendors understand and assess how mature and how well conducted their business processes are. The proposed maturity model has five maturity levels (i.e., ad hoc, active repeatable, proactive functional, pre-emptive managed, optimized). It also includes the characteristics that are necessary to achieve a particular level of maturity.

The remainder of the paper is organized as follows: Section 2 provides an overview of maturity models in related fields; Section 3 explains the research method used to construct the maturity model; Section 4 reveals the proposed maturity model for $\mathrm{C} 2 \mathrm{C}$ s-commerce; and finally, Section 5 presents the discussion, implications, and potential directions for future research.

\section{THEORETICAL BACKGROUND}

\subsection{C2C s-Commerce}

Liang and Turban ${ }^{22}$ classified s-commerce in terms of $\mathrm{B} 2 \mathrm{C}$ and $\mathrm{C} 2 \mathrm{C}$ business models. For $\mathrm{C} 2 \mathrm{C}$ s-commerce, this business model focuses on commercial activities transacted among users through social media. Obviously, large online retailers and other intermediaries are excluded from $\mathrm{C} 2 \mathrm{C}^{1}$.

To perform online transactions in this environment, users exploit the features and functionalities of social media technologies such as Facebook (e.g., Facebook personal profile, Facebook page, Facebook trade group, Facebook Messenger), Line (e.g., Line chat), and Instagram (e.g., Instagram profile) ${ }^{1}$.

\subsection{Maturity Models}

A maturity model performs organization capability assessment by presenting a sequence of maturity levels representing an anticipated, desired, or typical evolution path of organizations or processes that have very few 
capabilities at first and but acquire greater capabilities in their mature stages $^{6}$. To conduct s-commerce research, researchers need to pay attention to both business and technology $y^{22}$. Therefore, the review of literature focuses on maturity models in fields such as IS/IT, e-business, and social media adoption and management.

\subsubsection{Maturity Models in IS/IT Fields}

One of the most popular maturity models in software engineering is the Capability Maturity Model (CMM) proposed by Paulk et al. ${ }^{7}$ The model has been used in software development process improvement. The five levels of software process maturity are (1) initial, where the process is ad hoc, chaotic, and individually heroic; (2) repeatable, where the process repeats the steps of earlier successful projects; (3) defined, where all processes are defined as an organization's standard software processes; (4) managed, where the process and product quality are quantitatively measured and controlled; and (5) optimizing, where the process is continuously improved. In IT processes, the COBIT maturity model presents a way of evaluating an organization for IT process management and control ${ }^{8}$. The model has five levels of maturity: (1) initial/ad hoc, where the process is disorganized and not standard; (2) repeatable but intuitive, where the processes are performed by following a regular pattern; (3) defined process, where the process is documented, standardized, and communicated; (4) managed and measurable, where the process is monitored and measured for providing good practice; and (5) optimized, where the process is continuously improved and refined for good practice.

\subsubsection{Maturity Models in E-business Field}

Several researchers have proposed maturity models to understand the evolution of technology integration in traditional organizations. McKay, Marshall, and Prananto ${ }^{14}$ presented the six-stage SOG-e Model (Stages of Growth for E-business). The model uses seven indicators to explain the technological aspects of e-business growth: strategy, structure, systems, staff, style, skills, and superordinate goals. The first stage starts with no e-business activities in an organization due to waiting for a right time to investigate in online commerce. In the second stage, the organization establishes a static company website for one-way communication to customers. The third stage is marked by applications for two-way communication and customer interaction such as email, web browsers, and online forms for browsing, ordering products and services, and gathering information and feedback from customers. However, customers cannot complete transactions online. When it reaches the fourth stage, the organization's customers can complete transactions online and business 
processes are internet-based. Stage five beings the integration of the front and back offices are accomplished as well as business processes and structures that are reengineered for performance improvement. In the sixth and most mature stage, business processes and IT are combined into the entire organization.

Rao, Metts, and Monge ${ }^{15}$ offered a four-stage model to depict the growth patterns of e-commerce development in small- and medium-sized enterprises. The first stage is presence, in which a company provides a static website for product and service presentation, uses email for business communication, but offers no online transactions. In the second stage, portals, the company enables two-way communication and provides online transactions without online payment. In the third, transaction integration, the company can complete transactions conducted with both business partners and customers. There is a high level of internal but not external integration. Finally, enterprise integration, business collaboration and information sharing are well established among companies. Chan and Swatman's model $^{16}$ focused on organizational growth in B2B e-commerce. The model has four levels of maturity (i.e., initial e-commerce; centralized e-commerce initiative; looking inwards for benefits; and global e-commerce) described with five dimensions (strategy, structure, e-commerce technologies used, focus, and personnel). Case studies of ten organizations in Australia were conducted to develop and validate the model.

\subsubsection{Maturity Models of Social Media Adoption and Management}

To understand how social technologies transform companies, Corcoran's ${ }^{17}$ blog compared the maturity model with the five stages of the diffusion of innovation ${ }^{23}$. The five stages are (1) dormant, with no social media presence; (2) testing, where a company introduces social media; (3) coordinating, where the company encourages the use of social media; (4) scaling and optimizing, in which social media is integrated into the business process; and (5) empowering, where social media is deployed throughout the company.

Jussila, Kärkkäinen, and Lyytikkä ${ }^{18}$ presented their maturity model for social media adoption in innovation. The authors reviewed the literature and interviewed four key personnel of B2B companies to define and describe preliminary maturity dimensions: innovation-related processes, needed skills and competences, social media practices, incentives and motives for participation, and information security.

Duane and O'Reilly ${ }^{20}$ developed the management of social media business profile stages of a five-stage growth model. They also suggested 
evolutionary paths between stages and identified ten benchmark variables to measure an organization's growth and the problems that may arise across stages. To complete their study, they reviewed the literature on stages of growth models and many reports in related fields. They then empirically validated their model by collecting data from 52 organizations through a survey ${ }^{24}$.

Levina and Vilnai-Yavetz ${ }^{21}$ developed a social media adoption maturity model called the e-visibility maturity (e-VM) model by using a literature review, an international survey of online customers, and a comprehensive website review. The model focuses on organization capabilities to engage customers by using social media applications such as blogs, wikis, and social networks. Each stage of the model consists of four dimensions: interactivity, sociability, firm globalization, and security. The five stages of the model are: (1) invisibles, with no online presence; (2) beginners, who are starting to engage customers through online channels with many limitations in interactivity, sociability, and globalization; (3) practitioners, who still have some limitations for building customer engagement through social software; (4) sociables, who have a better integration of business processes and social applications within their organization; and (5) luminaries, who have a well implemented integration both dynamic and static social presence to engage with customers.

\section{DEVELOPMENT OF C2C S-COMMERCE MATURITY MODEL}

The development of the $\mathrm{C} 2 \mathrm{C}$ s-commerce maturity model iteratively applied secondary and case study research to identify maturity levels and important dimensions of a new model and to determine the characteristics of each maturity level. Figure 1 depicts the model development. 


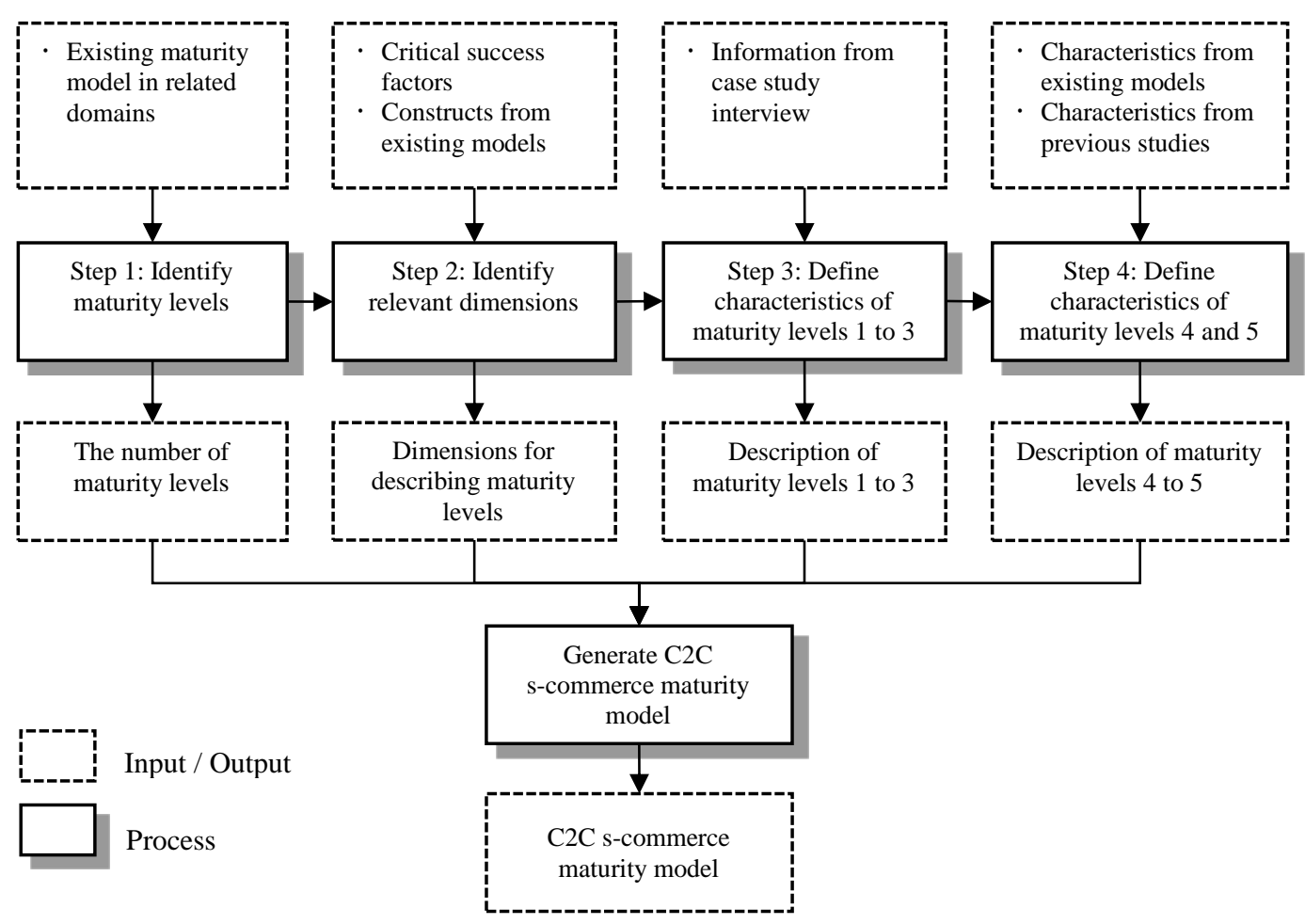

Figure 1. Procedure for the development of $\mathrm{C} 2 \mathrm{C}$ s-commerce maturity model

\subsection{The Identification of Maturity Levels}

In the initial stage of the maturity model development proposed by Becker, Knackstedt, and Pöppelbu $\beta^{6}$, they identified a fixed number of maturity levels and defined the dimensions of the model by reviewing the literature and using the comparison with existing maturity models. The first step of $\mathrm{C} 2 \mathrm{C}$ maturity model development is the identification of maturity levels. Comprehensive reviews of literature were conducted by searching a variety of academic electronic databases for and using the models in IS/IT fields such as software development processes, IT processes, e-business, e-commerce, and social media management. In addition, we reviewed reports, white papers, websites, and blogs. According to the findings of the literature review (Table 1), we have constructed a five-level maturity model: (1) ad hoc; (2) active repeatable; (3) proactive functional; (4) pre-emptive managed; and (5) optimized. 


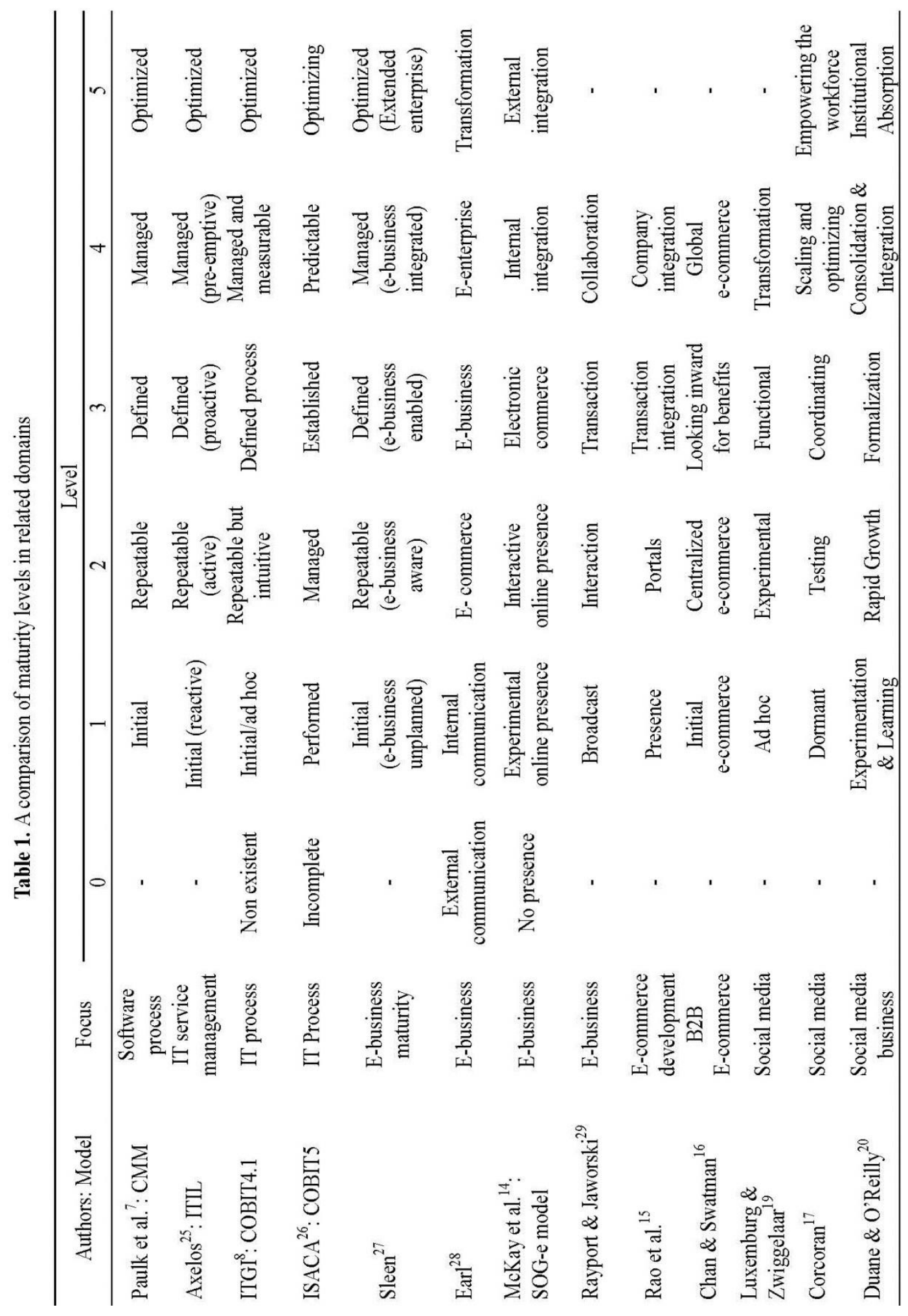




\subsection{The Identification of Relevant Dimensions}

Following the typology suggested by Fraser, Moultrie, and Gregory ${ }^{30}$, each level of all maturity models consists of several dimensions with specific activities and the description of these activities. In the next step, we investigated the current maturity models and critical success factors in the context of e-business, e-commerce, and s-commerce to explore the important constructs related to online business and social media technology domains. These sources enabled us to define specific dimensions of the model that would be used to explain the distinctive characteristics of each level. Table 2 displays the constructs reported by several researchers. The C2C s-commerce maturity model identified the dimensions of business environment, people, process, and technology. Business environment evaluates the extent of having business goals, objectives, and strategies for performing online business. People refer to the maturity of capabilities, experience, or skills of individuals or groups for business implementation. Process refers to the maturity of vendors to perform a business activity or a set of activities, methods, or practices when implementing C2C s-commerce in order to achieve their goals. Technology evaluates the extent of the use of IT or IS resources for C2C s-commerce implementation.

Table 2. The investigation of constructs in related domains

\begin{tabular}{|c|c|c|}
\hline $\begin{array}{l}\text { Defined } \\
\text { dimension }\end{array}$ & Constructs & Authors \\
\hline \multirow[t]{5}{*}{$\begin{array}{l}\text { Business } \\
\text { environment }\end{array}$} & Strategy & $\begin{array}{l}\text { Galliers and Sutherland }{ }^{31} \text {; Chan and } \\
\text { Swatman }^{16} ; \text { Lehmkuhl, Baumöl, and }^{32} \\
\text { Jung }^{32}\end{array}$ \\
\hline & Commitment & Corcoran $^{17}$ \\
\hline & Management and organization & Sleen $^{27} ;$ Liang and Turban ${ }^{22}$ \\
\hline & Mission, support, and strategy & Camiade and Claisse ${ }^{33}$ \\
\hline & $\begin{array}{l}\text { Strategy, management, and } \\
\text { Organization-culture }\end{array}$ & Laosethakul and Boulton ${ }^{34}$ \\
\hline \multirow[t]{9}{*}{ People } & Staff/skills & Galliers and Sutherland ${ }^{31}$ \\
\hline & Personnel involved & Chan and Swatman ${ }^{16}$ \\
\hline & Needed skills and competence & Jussila, Kärkkäinen, and Lyytikkä ${ }^{18}$ \\
\hline & Experience, culture, resources & Corcoran ${ }^{17}$ \\
\hline & Culture & Lehmkuhl, Baumöl, and Jung ${ }^{32}$ \\
\hline & $\mathrm{HR}$ & Camiade and Claisse ${ }^{33}$ \\
\hline & People and culture & Sleen $^{27}$ \\
\hline & Worker & Laosethakul and Boulton ${ }^{34}$ \\
\hline & People & Wang and Zhang ${ }^{35}$ \\
\hline
\end{tabular}


Table 2. The investigation of constructs in related domains (con.)

\begin{tabular}{|c|c|c|}
\hline $\begin{array}{l}\text { Defined } \\
\text { dimension }\end{array}$ & Constructs & Authors \\
\hline \multirow[t]{6}{*}{ Process } & Social media practices & Jussila, Kärkkäinen, and Lyytikkä ${ }^{18}$ \\
\hline & Processes & Corcoran $^{17} ;$ Wang and Zhang ${ }^{35}$ \\
\hline & $\begin{array}{l}\text { Social media marketing and } \\
\text { enterprise management }\end{array}$ & Liang and Turban ${ }^{22}$ \\
\hline & Processes and organization & Lehmkuhl, Baumöl, and Jung ${ }^{32}$ \\
\hline & processes and procedures & Sleen $^{27}$ \\
\hline & $\begin{array}{l}\text { Marketing, customer/supplier } \\
\text { service/support, business process }\end{array}$ & Laosethakul and Boulton $^{34}$ \\
\hline \multirow[t]{8}{*}{ Technology } & Systems & $\begin{array}{l}\text { Galliers and Sutherland }{ }^{31} \text {; Lehmkuhl, } \\
\text { Baumöl, and Jung }{ }^{32}\end{array}$ \\
\hline & E-commerce technologies used & Chan and Swatman ${ }^{16}$ \\
\hline & Innovation-related processes & Jussila, Kärkkäinen, and Lyytikkä ${ }^{18}$ \\
\hline & Technology support integration & Liang and Turban ${ }^{22}$ \\
\hline & Tools & Camiade and Claisse ${ }^{33}$ \\
\hline & IT and infrastructure & Sleen $^{27}$ \\
\hline & Website and technology & Laosethakul and Boulton $^{34}$ \\
\hline & Technology & Wang and Zhang ${ }^{35}$ \\
\hline
\end{tabular}

\subsection{Defining Characteristics of Maturity Levels 1 To 3}

Yin $^{36}$ stated that a case study approach has been used to examine a contemporary phenomenon. Therefore, a case study interview was conducted to understand how a vendor implements or performs business in a C2C s-commerce environment. An in-depth interview method was adopted for data collection. The seven interviewees were experienced in business implementation through Facebook and were selected because they displayed diversity in the type of products for sale, business experience, and sales channels (Table 3). The semi-structured interviews were done by phone and, on average, lasted about one hour. The interviewees were asked to express their opinions on business direction since starting their business. 
Table 3. Case study demographic information

\begin{tabular}{|c|c|c|c|}
\hline Vendor & Experience (Year) & Product type & Sales channel \\
\hline A & $<1$ & Cosmetics & Facebook personal profile \\
\hline $\mathrm{B}$ & $<1$ & Handmade Products & Facebook page \\
\hline $\mathrm{C}$ & $1-2$ & $\begin{array}{l}\text { Beauty Products, Sport } \\
\text { shoes, Bedding set, } \\
\text { Handbag }\end{array}$ & Facebook personal profile \\
\hline $\mathrm{D}$ & $1-2$ & $\begin{array}{l}\text { Books and Clothes for } \\
\text { Kids }\end{array}$ & $\begin{array}{l}\text { Facebook page and trade } \\
\text { group }\end{array}$ \\
\hline $\mathrm{E}$ & $2-3$ & Beauty Products & Facebook personal profile \\
\hline $\mathrm{F}$ & $3-4$ & Clothes for Kids & Facebook personal profile \\
\hline G & $>6$ & $\begin{array}{l}\text { Fashion shoes, } \\
\text { Imported Products, } \\
\text { Clothes }\end{array}$ & $\begin{array}{l}\text { Facebook personal profile } \\
\text { and trade group, Instagram, } \\
\text { Twitter }\end{array}$ \\
\hline
\end{tabular}

To explain the maturity levels from the case data, we identified the characteristics of each proposed dimension from the first case and analyzed the second case to modify the initial model. Then, we modified and refined the model from the third to the seventh cases until the model demonstrated convergence and stability. The results of the case interviews helped us understand the growth patterns of business implementation and relevant characteristics of the maturity levels 1 to 3 . The list of characteristics of maturity levels 1 to 3 have been summarized from the case study interviews and presented in Table 4.

Table 4. The characteristics of maturity levels 1 to 3 from case study interviews

\begin{tabular}{|c|c|c|c|}
\hline Level & Characteristics & $\begin{array}{l}\text { Reference } \\
\text { (vendors) }\end{array}$ & Selected quotes from vendors \\
\hline \multirow[t]{4}{*}{1} & $\begin{array}{l}\text { There is little or no } \\
\text { experience when starting } \\
\text { business through SNSs. }\end{array}$ & $\begin{array}{l}\text { A, B, C, D, } \\
\text { E, F, G }\end{array}$ & $\begin{array}{l}\text { "I have no experience of selling } \\
\text { products through Facebook" } \\
\text { (Vendor A) }\end{array}$ \\
\hline & $\begin{array}{l}\text { There is no systematic } \\
\text { process, strategy, plan, or } \\
\text { even goal to perform online } \\
\text { business. }\end{array}$ & $\begin{array}{l}\text { A, B, C, D, } \\
\text { E, F, G }\end{array}$ & $\begin{array}{l}\text { "I sell products via Facebook for } \\
\text { extra income, so I never defined a } \\
\text { goal or plan" (Vendor B) }\end{array}$ \\
\hline & $\begin{array}{l}\text { Vendors learn how to } \\
\text { perform business through } \\
\text { various sources: }\end{array}$ & $\mathrm{A}, \mathrm{B}, \mathrm{C}, \mathrm{D}$ & $\begin{array}{l}\text { "I observed other vendors and } \\
\text { searched for articles posted by } \\
\text { experts to know how to conduct }\end{array}$ \\
\hline & $\begin{array}{l}\text { 1) observing other merchants } \\
\text { selling similar products; and } \\
\text { 2) reading articles from } \\
\text { experts' blogs. }\end{array}$ & $\mathrm{B}, \mathrm{C}, \mathrm{D}$ & $\begin{array}{l}\text { business marketing and promote } \\
\text { products on Facebook and applied } \\
\text { that knowledge to my products" } \\
\text { (Vendor D) }\end{array}$ \\
\hline
\end{tabular}


Table 4. The characteristics of maturity levels 1 to 3 from case study interviews (con.)

\begin{tabular}{|c|c|c|c|}
\hline Level & Characteristics & $\begin{array}{l}\text { Reference } \\
\text { (vendors) }\end{array}$ & Selected quotes from vendors \\
\hline \multirow[t]{10}{*}{2} & $\begin{array}{l}\text { Business operation and } \\
\text { management are based on } \\
\text { experience with prior } \\
\text { transactions and business } \\
\text { process are established to } \\
\text { repeat earlier successes of } \\
\text { transactions. }\end{array}$ & $\begin{array}{l}\text { A, B, C, D, } \\
\text { E, F, G }\end{array}$ & $\begin{array}{l}\text { "I changed business processes and } \\
\text { strategies until my products could } \\
\text { be sold and I applied them to } \\
\text { forthcoming transactions." (Vendor } \\
\text { C) }\end{array}$ \\
\hline & $\begin{array}{l}\text { Business goal, plan, and } \\
\text { strategy are defined but } \\
\text { unclear. }\end{array}$ & $\begin{array}{l}\text { C, D, E, F, } \\
\text { G }\end{array}$ & $\begin{array}{l}\text { "I don't have an obvious business } \\
\text { goal or plan." (Vendor E) }\end{array}$ \\
\hline & $\begin{array}{l}\text { Business strategy focuses on } \\
\text { the presentation of products } \\
\text { to prospective customers. }\end{array}$ & $\begin{array}{l}\text { A, B, C, D, } \\
\text { E, F, G }\end{array}$ & $\begin{array}{l}\text { "Marketing strategy is an } \\
\text { important factor for business } \\
\text { success especially in the startup } \\
\text { phase." (Vendor A) }\end{array}$ \\
\hline & $\begin{array}{l}\text { Vendors invest in online } \\
\text { advertisement provided by } \\
\text { platform providers in the } \\
\text { initial stage. }\end{array}$ & $\mathrm{F}, \mathrm{G}$ & $\begin{array}{l}\text { "When I started up my business, I } \\
\text { spent money on advertising on } \\
\text { Facebook. After the values of sales } \\
\text { increased and gaining many } \\
\text { customers, I decreased my } \\
\text { investigation and conducted online } \\
\text { marketing by myself." (Vendor F) }\end{array}$ \\
\hline & $\begin{array}{l}\text { - Vendors pay attention to } \\
\text { build consumers' trust by } \\
\text { using electronic word of } \\
\text { mouth (E-WOM) and } \\
\text { product reviews created by } \\
\text { both vendors themselves and } \\
\text { experienced customers. } \\
\text { - In order to manage an order } \\
\text { list, vendors use: }\end{array}$ & $\begin{array}{l}\text { A, B, C, D, } \\
\text { E, F, G }\end{array}$ & $\begin{array}{l}\text { "I attempted to review my products } \\
\text { and share product reviews sent } \\
\text { from customers to build trust." } \\
\text { (Vendor } C \text { ) }\end{array}$ \\
\hline & $\begin{array}{l}\text { 1) a traditional method by } \\
\text { writing an order list into a }\end{array}$ & A, B & $\begin{array}{l}\text { "I wrote orders in a notebook." } \\
\text { (Vendor B) }\end{array}$ \\
\hline & $\begin{array}{l}\text { 2) searching for an order list } \\
\text { from message logs that } \\
\text { customers place an order by } \\
\text { sending messages via SNSs' }\end{array}$ & & $\begin{array}{l}\text { "I always look for an order from } \\
\text { Facebook Messenger chat history } \\
\text { and Line Chat history." (Vendor E) }\end{array}$ \\
\hline & $\begin{array}{l}\text { communication functions such } \\
\text { as Line Chat, Facebook }\end{array}$ & $\mathrm{F}, \mathrm{G}$ & \\
\hline & Messenger; and & & "I have saved my order lists into \\
\hline & $\begin{array}{l}\text { 3) recording data into office } \\
\text { application, such as } \\
\text { spreadsheets in cases of } \\
\text { having many order lists. }\end{array}$ & & MS Excel" (Vendor F) \\
\hline
\end{tabular}


Table 4. The characteristics of maturity levels 1 to 3 from case study interviews (con.)

\begin{tabular}{|c|c|c|c|}
\hline Level & Characteristics & $\begin{array}{l}\text { Reference } \\
\text { (vendors) }\end{array}$ & Selected quotes from vendors \\
\hline \multirow[t]{4}{*}{3} & $\begin{array}{l}\text { Business goal is evidently } \\
\text { defined. }\end{array}$ & $\mathrm{F}$ & $\begin{array}{l}\text { "Previously, I never defined a } \\
\text { business goal; now I set my goal to } \\
\text { earn [...] baht a month." (Vendor } \\
\text { F) }\end{array}$ \\
\hline & $\begin{array}{l}\text { - Business strategy focuses on } \\
\text { customer acquisition and } \\
\text { customer retention. }\end{array}$ & $\mathrm{F}, \mathrm{G}$ & $\begin{array}{l}\text { "I have maintained new and } \\
\text { existing customers for repeat } \\
\text { purchases by selling quality } \\
\text { products at a cheap rate and using } \\
\text { e-WOM." (Vendor } G \text { ) }\end{array}$ \\
\hline & $\begin{array}{l}\text { Business processes are } \\
\text { standardized from previous } \\
\text { experience. }\end{array}$ & $\mathrm{F}, \mathrm{G}$ & $\begin{array}{l}\text { "After having enough experience, I } \\
\text { can define business process clearly } \\
\text { and then I adapt this standardized } \\
\text { process to my business." (Vendor } \\
F)\end{array}$ \\
\hline & $\begin{array}{l}\text { Vendors expand their } \\
\text { business by offering new } \\
\text { products to customers in } \\
\text { different groups. }\end{array}$ & $\mathrm{F}, \mathrm{G}$ & $\begin{array}{l}\text { "Now I have four Facebook } \\
\text { personal profiles for selling four } \\
\text { different products. I have exploited } \\
\text { Facebook personal profiles for } \\
\text { adults and elderly people and have } \\
\text { adopted Instagram and Twitter for } \\
\text { product presentation when the } \\
\text { target audience are adolescents." } \\
\text { (Vendor G) }\end{array}$ \\
\hline
\end{tabular}

\subsection{Defining Characteristics of Maturity Levels 4 And 5}

Maturity levels 4 and 5 are relatively unknown areas for the $\mathrm{C} 2 \mathrm{C}$ s-commerce business model. It is difficult to draw conclusions about the characteristics of maturity level 4 and 5 vendors due to the lack of examples. Similarly, the development of other maturity models such as CMM7 could not be developed by adapting the characteristics of real level 4 and 5 organizations from software projects or organizations. Therefore, the maturity levels 4 and 5 of the proposed model are characterized by analogy with the maturity models in related disciplines, such as frameworks for organization performance assessment (e.g., the Baldrige Excellence Framework), and prior research. Table 5 lists the characteristics of maturity levels 4 and 5 collected from other maturity models and previous studies . 
Table 5. The characteristics of maturity levels 4 and 5 from the literature

\begin{tabular}{|c|c|c|c|}
\hline Level & Dimension & Characteristics & Authors: model \\
\hline \multirow[t]{12}{*}{4} & $\begin{array}{l}\text { Business } \\
\text { environment }\end{array}$ & $\begin{array}{l}\text { Efficiency and effectiveness are measured } \\
\text { and linked to business goals. }\end{array}$ & $\begin{array}{l}\text { ITGI }^{8}: \text { COBIT4.1; } \\
\text { Axelos }^{25}: \text { ITIL level 4; } \\
\text { Willner, Gosling, and } \\
\text { Schönsleben }\end{array}$ \\
\hline & & $\begin{array}{l}\text { - Business focuses on customer and service } \\
\text { outcomes. }\end{array}$ & Axelos $^{25}:$ ITIL level 4 \\
\hline & & $\begin{array}{l}\text { Improvement measures are defined to } \\
\text { improve the performance }\end{array}$ & $\begin{array}{l}\text { Willner, Gosling, and } \\
\text { Schönsleben }^{37}\end{array}$ \\
\hline & People & $\begin{array}{l}\text { People can adopt and adapt technologies in } \\
\text { response to technological developments }\end{array}$ & $\begin{array}{l}\text { Kerrigan }^{38} \text {; Curtis, Hefley, } \\
\text { and Miller } \\
\text { 49 P-CMM level } \\
4 \text {; Gill and VanBoskirk }{ }^{40} \text { : } \\
\text { Digital Maturity Model } \\
\text { (level 3) }\end{array}$ \\
\hline & & $\begin{array}{l}\text { The organization creates a culture of } \\
\text { measurement and exploits shared } \\
\text { experience. }\end{array}$ & $\begin{array}{l}\text { Curtis, Hefley, and Miller }{ }^{39} \text { : } \\
\text { P-CMM level } 4\end{array}$ \\
\hline & & $\begin{array}{l}\text { The organization has the capability to } \\
\text { predict its performance and capacity for } \\
\text { work. }\end{array}$ & $\begin{array}{l}\text { Curtis, Hefley, and Miller }{ }^{39} \text { : } \\
\text { P-CMM level } 4\end{array}$ \\
\hline & Process & $\begin{array}{l}\text { There is an effective and systematic } \\
\text { process. }\end{array}$ & $\begin{array}{l}\text { Paulk et al. }{ }^{7} \text { : CMM Level 4; } \\
\text { ITGI }^{8}: \text { COBIT Level 4; } \\
\text { Axelos }^{25}: \text { ITIL Level 4; } \\
\text { NIST }^{41}: \text { Baldrige process } \\
\text { scoring at } 50-65 \%\end{array}$ \\
\hline & & - There are process measuring and control. & $\begin{array}{l}\text { Paulk et al. }{ }^{7} \text { : CMM Level 4; } \\
\text { ITGI }^{8}: \text { COBIT Level 4; } \\
\text { Axelos }^{25}: \text { ITIL Level 4; } \\
\text { NIST }^{41}: \text { Baldrige process } \\
\text { scoring at } 50-65 \%\end{array}$ \\
\hline & & $\begin{array}{l}\text { - There are process evaluation and } \\
\text { improvement. }\end{array}$ & $\begin{array}{l}\text { Paulk et al. }{ }^{7} \text { : CMM Level 4; } \\
\text { ITGI }^{8}: \text { COBIT Level 4; } \\
\text { Axelos }^{25}: \text { ITIL Level 4; } \\
\text { NIST }^{41}: \text { Baldrige process } \\
\text { scoring at } 50-65 \%\end{array}$ \\
\hline & Technology & $\begin{array}{l}\text { Technologies are used for the involvement } \\
\text { of customers and suppliers in product } \\
\text { development (e.g., design, modeling, } \\
\text { simulation, and testing). }\end{array}$ & $\begin{array}{l}\text { Chung et al. } \\
\text { Heller and Varney } \\
{ }^{42}\end{array}$ \\
\hline & & $\begin{array}{l}\text { - Technologies are used for the evaluation of } \\
\text { marketing strategies in order to improve the } \\
\text { business (e.g., analysis, measurement, and } \\
\text { reporting). }\end{array}$ & Chung et al. ${ }^{24}$ \\
\hline & & $\begin{array}{l}\text { Technologies are used for internal use (i.e., } \\
\text { advertising vacancies, special interest } \\
\text { groups) }\end{array}$ & Chung et al. ${ }^{24}$ \\
\hline
\end{tabular}


Table 5. The characteristics of maturity levels 4 and 5 from the literature (con.)

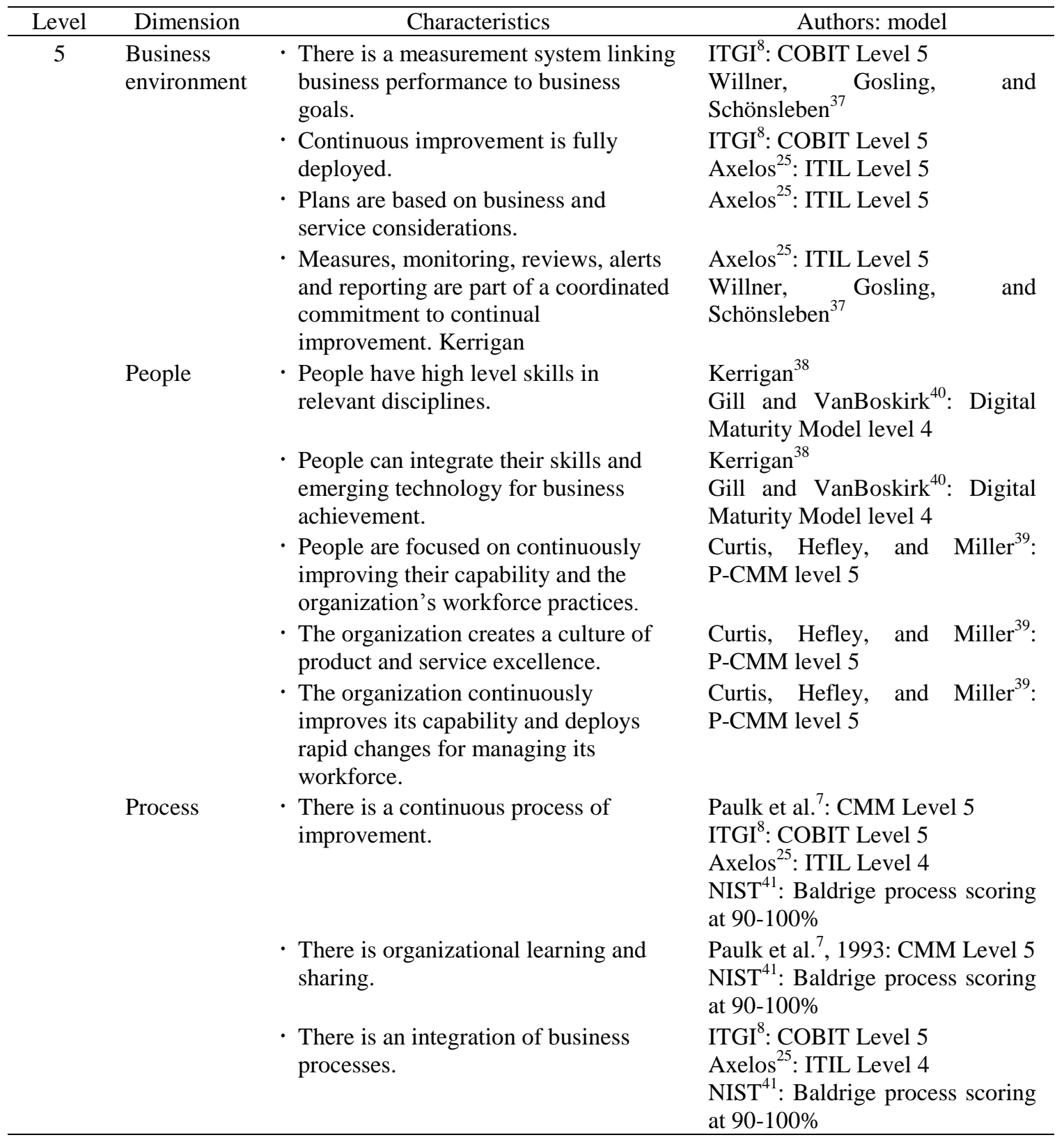


Table 5. The characteristics of maturity levels 4 and 5 from the literature (con.)

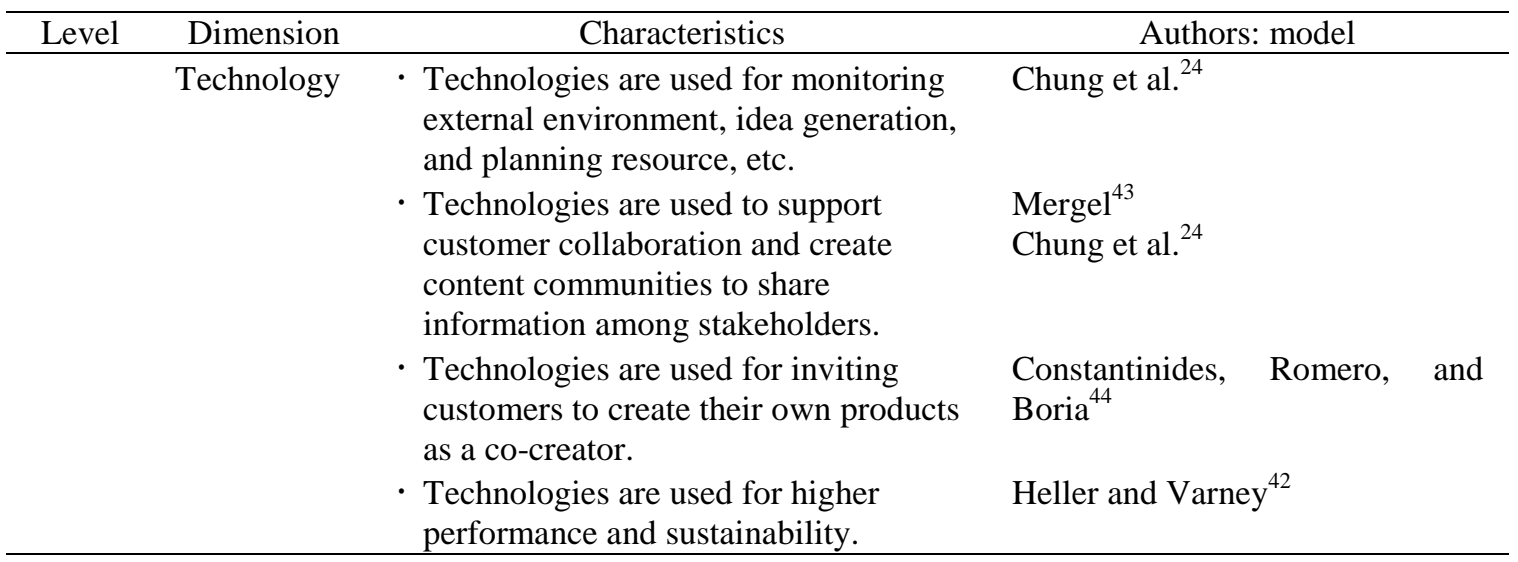

According to Table 5, maturity levels 4 and 5 of the $\mathrm{C} 2 \mathrm{C}$ s-commerce business model can be described as follows:

\subsubsection{Description of Maturity Level 4}

The focus of the level 4 vendor is the effectiveness of the $\mathrm{C} 2 \mathrm{C}$ business model (i.e., vendor's product ordering, order processing and payment, product delivery, sales and marketing, and after-sales services). A vendor should set quantitative goals and control process performance quantitatively. Business processes should be monitored, controlled, and constantly improved to achieve business goals. Business outcomes are also measured for important business process activities across all transactions and products by collecting and analyzing the data for the improvement of business processes and marketing strategy performance. The output of each business approach should be monitored to ensure that performance meets the standard. The vendor should pay more attention to customer and service outcomes than to technological considerations. Business operation should be customer-focused. For a positive customer experience, a customer-centric strategy should be established throughout the consumer decision-making process to drive repeat business transactions, create customer engagement and loyalty, and increase profits.

\subsubsection{Description of maturity level 5}

This level responds to the effectiveness of several approaches. For example, for order processing and payment, the vendor has to concentrate on all activities related to consumer order management such as placing and confirming an order, payment, and delivery. For the mature level of $\mathrm{C} 2 \mathrm{C}$ 
s-commerce, a vendor should monitor its business processes and innovative technologies to improve business efficiency and effectiveness in a way that would lead to competitive advantage. The retained data such as business performance and customer feedback would be analyzed for improvement potential to assess the effectiveness and quality of the process outcomes, and customers' requirements and expectations.

\section{C2C S-COMMERCE MATURITY MODEL}

Based on the analysis of the seven cases and the information from prior literature, we develop and propose a $\mathrm{C} 2 \mathrm{C}$ s-commerce maturity model that vendors (whether individuals or small online retailers) can use to assess the maturity of their business arrangement and to improve their capabilities, strategies, and processes. After identifying the levels and dimensions of maturity, their characteristics are detailed and presented in Table 6.

\section{DISCUSSION AND CONCLUSION}

Due to a lack of research studies on s-commerce in a $\mathrm{C} 2 \mathrm{C}$ business model, this paper sheds light on how SNS subscribers in developing countries like Thailand implement online business among users to understand the evolution of business direction in the $\mathrm{C} 2 \mathrm{C}$ context. This study presents a maturity model that represents the growth patterns of business arrangements. The model identifies five maturity levels and guides vendors in assessing the stage of their business and their own capabilities. Additionally, the model presents four criteria (business environment, people, process, and technology) that need to be fulfilled to move to higher levels. Therefore, the proposed model guides SNS users (vendors) to improve their business in practice. To benefit from the model, vendors must identify the level of maturity they have reached they in order to learn from vendors on the same level, and understand how to conduct business to reach the higher levels.

The model was based on secondary research and on data collected from interviews with representatives of the seven case studies. The case interviews have given some insight to the business activities at the first three levels of maturity. Levels 4 and 5 were characterized from current and previous literature in related areas. Through our research methodology, the study has important theoretical implications. This study provided an approach that can generate new maturity models in other $\mathrm{C} 2 \mathrm{C}$ business models or to describe new phenomena that may be rare in real organizations. 


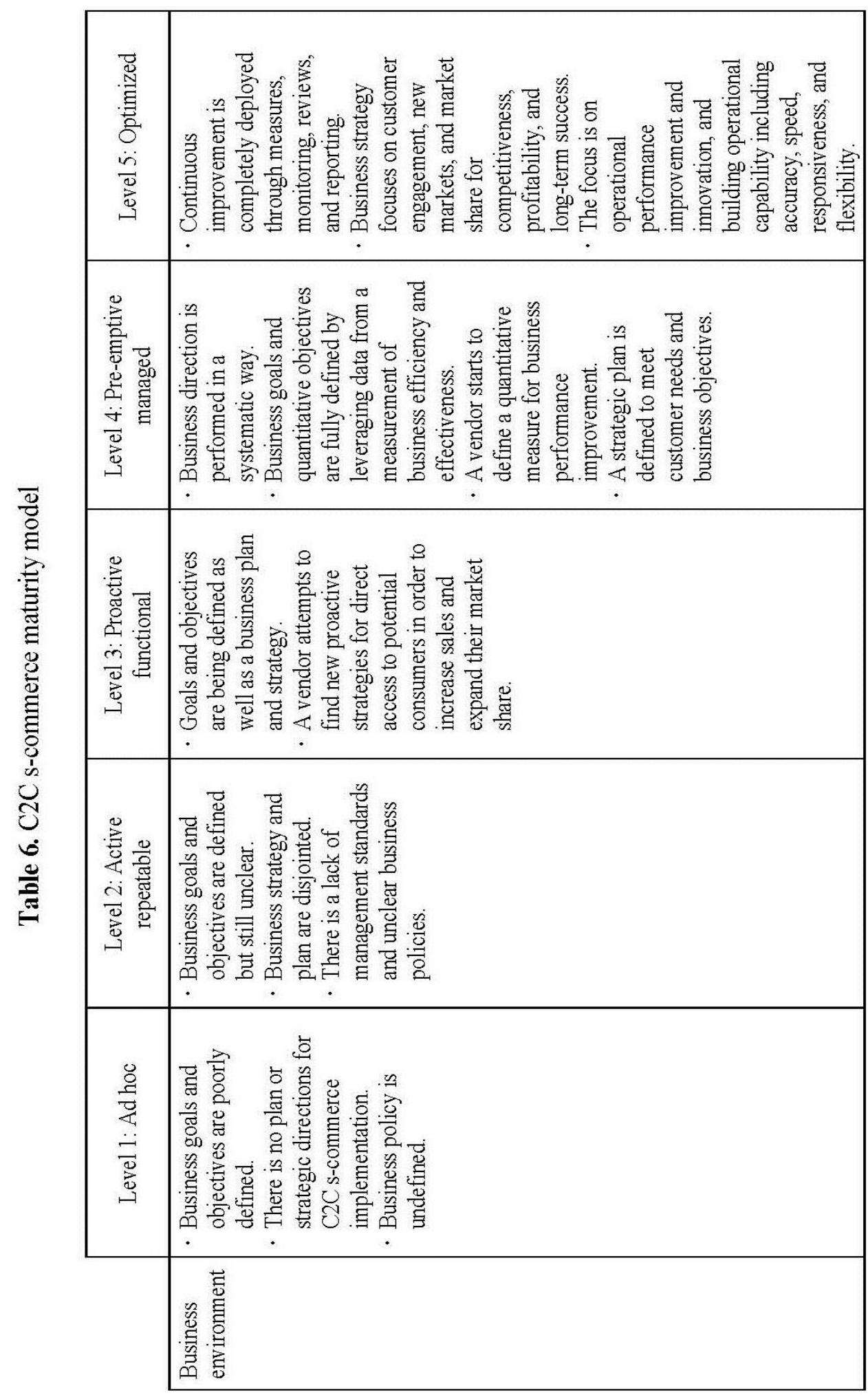




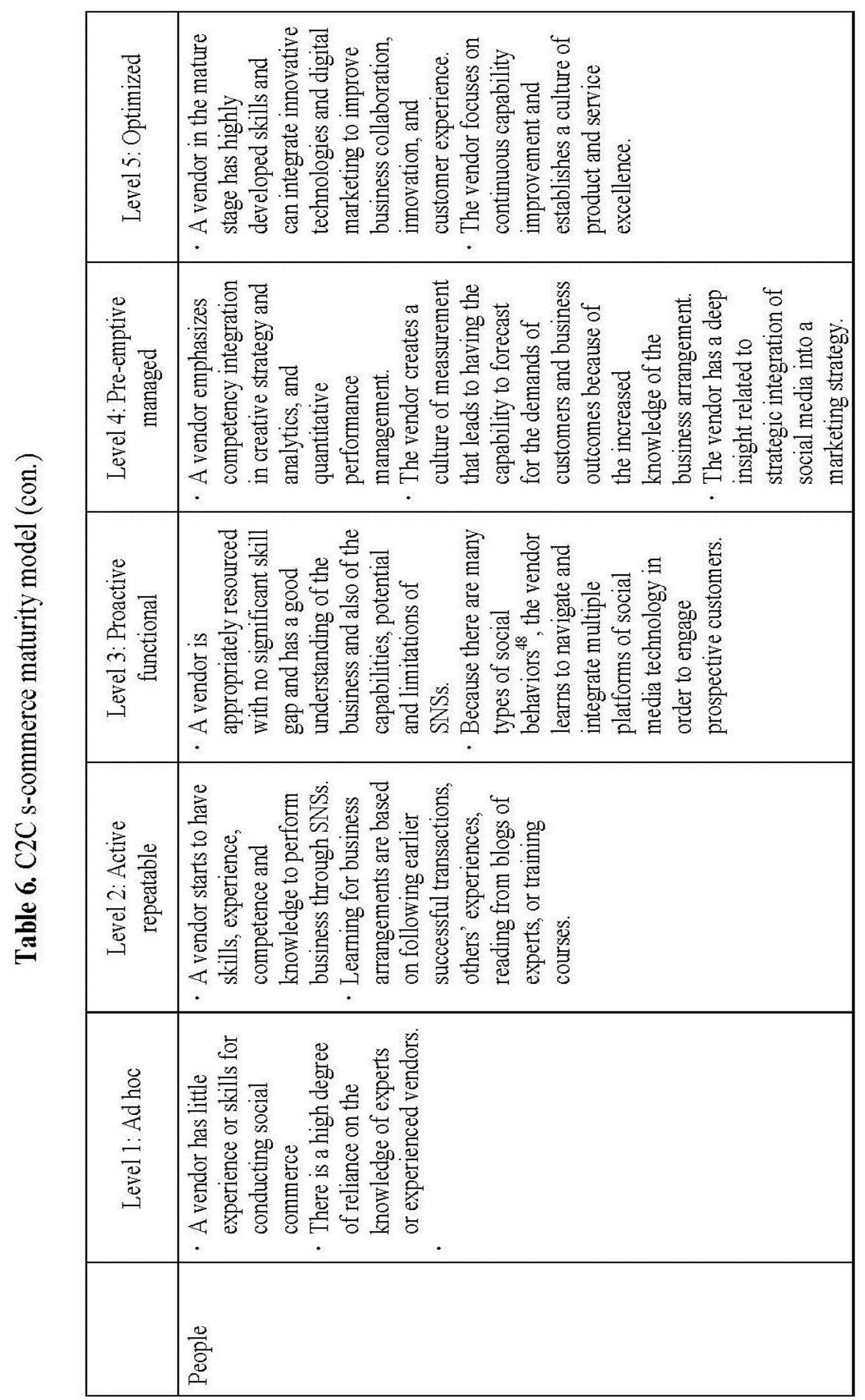




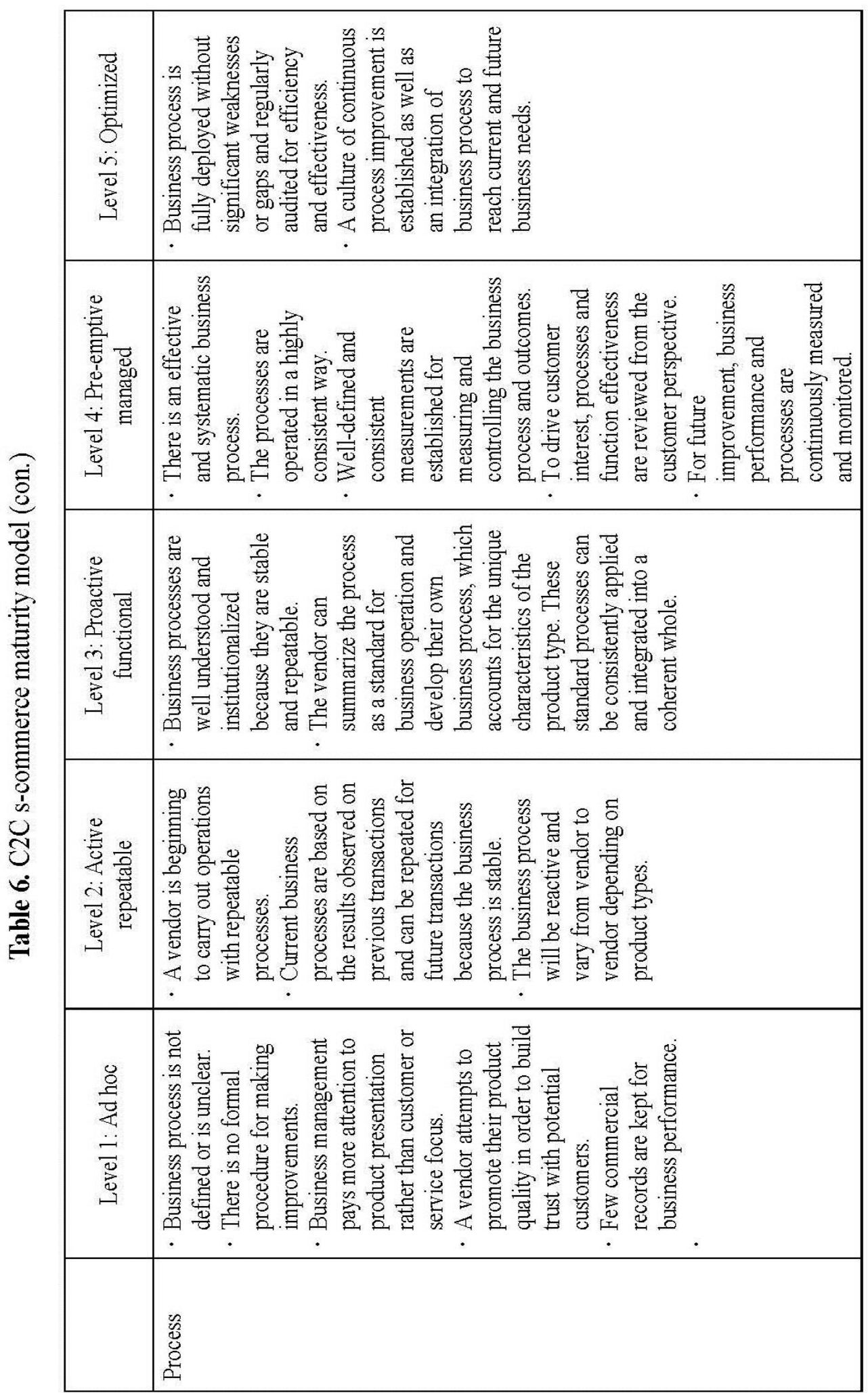




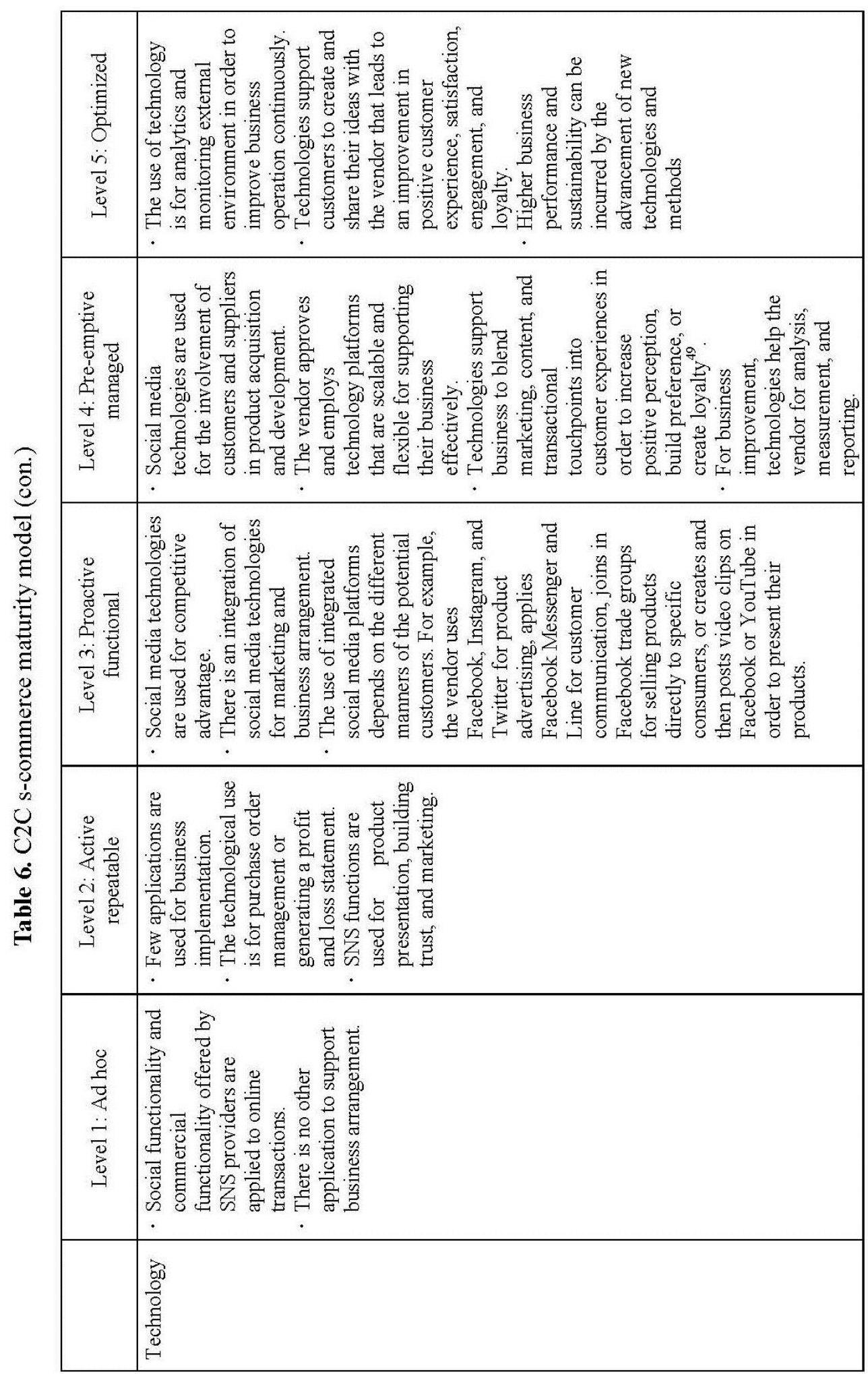


The information presented in the maturity model can help vendors identify gaps and assess their business to reduce risks of business failure. When business activities are highly consistent and systematic, consumers place greater trust in vendors. Consumers can assume vendors with high maturity regularly fulfill their commitments.

From the case study interviews, we found that these vendors are at maturity level 3 . To reach maturity level 4 , the vendor should measure and monitor their business operations through either free or paid social media analytics tools and then translate analytics information into action plans that will enhance business processes and capabilities. However, it may not always be suitable for an individual to invest in premium services offered by SNS providers ${ }^{24}$. Choo ${ }^{45}$ proposed the typology of information culture and claimed that the pattern of information use within an organization depends on its stage of growth. Following Choo's typology, vendors in high levels of $\mathrm{C} 2 \mathrm{C}$ s-commerce should use internal information to understand customers and competitors, to assess performance, to control business operations, to standardize processes and to improve business efficiency. For vendors in the mature stage, external information should be used to evaluate business performance and achievement.

This study provides some limitations and recommendations for future studies. For the first limitation, many types of products are merchandized through SNS. Future research should pay attention to the relation between product type and maturity level and subsequent effect on consumer purchase intention. Second, this study is concerned with commercial activities among Thai SNS users. Future research can expand this study to vendors in different countries and increase the number of case studies. Prior studies have found that cultural differences affect patterns of social media use $\mathrm{s}^{46,47}$. Vendors in different countries are expected to have different patterns of C2C s-commerce. Third, this study proposes a conceptual maturity model of $\mathrm{C} 2 \mathrm{C}$ s-commerce. An empirical study may be needed to examine how the levels evolve with respect to each dimension. Fourth, the maturity model was developed with cases from $\mathrm{C} 2 \mathrm{C}$ s-commerce environments. Future investigations may assess the model applicability in the business environments more generally. Fifth, other associated dimensions can be added to the model in order to describe the different levels. Lastly, the model should be improved and all maturity levels, especially levels 4 and 5, be revised because the characteristics of such vendors are less known. 


\section{REFERENCES}

[1] S. Sukrat, P. Mahatanankoon, and B. Papasratorn, The evolution of C2C social commerce models. Paper presented at the Eleventh International Conference on Digital Information Management, Porto, Portugal, September 19-21, 2016. http://dx.doi.org/10.1109/ICDIM.2016.7829761.

[2] Statista, Number of social media users worldwide from 2010 to 2020. Retrieved on January 21, 2016, from https://www.statista.com/statistics/278414/number-of-worldwide-social -network-users.

[3] eMarketer, Southeast Asia has among the highest social network usage in the world. Retrieved on January 21, 2016, from http://www.emarketer.com/Article/Southeast-Asia-Has-Among-Highes t-Social-Network-Usage-World/1013275.

[4] J. Russell, Page365 Grabs $\$ 420 K$ To Professionalize Social Commerce In Southeast Asia, Starting In Thailand. Retrieved on February 22, 2016, from https://techcrunch.com/2014/12/11/page365-seed-funding-thailan d.

[5] ETDA, Value of e-commerce survey in Thailand 2016. Retrieved on January 21, 2016, from https://www.etda.or.th/download-publishing/65.

[6] J. Becker, R. Knackstedt, and D. W. I. J. Pöppelbuß, Developing maturity models for IT management. Business \& Information Systems Engineering, $1(3)$, p213-222, 2009. http://dx.doi.org/10.1007/s12599-009-0044-5.

[7] M. C. Paulk, B. Curtis, M. B. Chrissis, and C. V. Weber, Capability maturity model, version 1.1. IEEE Software, 10(4), p18-27, 1993. http://dx.doi.org/10.1109/52.219617.

[8] ITGI, Cobit 4.1 Executive Summary. Retrieved on January 21, 2016, from https://www.isaca.org/Knowledge-Center/cobit/Documents/COBIT4.pdf.

[9] J. Lee, D. Lee, S. Kang, An overview of the business process maturity model (BPMM). In K. C. Chang, W. Wang, L. Chen, C. A. Ellis, C. H. Hsu, A. C. Tsoi, H. Wang, X. Lin, Y. Yang, J. Xu (Eds.), Advances in 
Web and Network Technologies, and Information Management, Berlin, Germany: Springer, 2007. http://dx.doi.org/10.1007/978-3-540-72909-9_42.

[10] Jr, P. Mendes, J. E. Leal, and A. M. T. Thomé, A maturity model for demand-driven supply chains in the consumer product goods industry. International Journal of Production Economics, 179, p153-165, 2016. http://dx.doi.org/10.1016/j.ijpe.2016.06.004.

[11] F. L. A. Oliva, Aturity model for enterprise risk management. International Journal of Production Economics, 173, p66-79, 2016. http://dx.doi.org/10.1016/j.ijpe.2015.12.007.

[12] S. Marshall, and G. Mitchell, An e-learning maturity model. Paper Presented at the Proceedings of the 19th Annual Conference of the Australian Society for Computers in Learning in Tertiary Education, Auckland, New Zealand, December 8-11, 2002.

[13] G. Lee, and Y. H. Kwak, An Open Government Maturity Model for social media-based public engagement. Government Information Quarterly, 29(4), p492-503, 2012. http://dx.doi.org/10.1016/j.giq.2012.06.001.

[14] J. McKay, P. Marshall, and A. Prananto, Stages of maturity for e-business: The SOG-e model. Proceedings of the Fourth Pacific Asia Conference on Information Systems (p29-43). Hong Kong: Hong Kong University of Science and Technology, 2000.

[15] S. S. Rao, G. Metts, and C. A. M. Monge, Electronic commerce development in small and medium sized enterprises: A stage model and its implications. Business Process Management Journal, 9(1), 11-32, 2003. http://dx.doi.org/10.1108/14637150310461378.

[16] C. Chan, and P. M. C. Swatman, B2B e-commerce stages of growth: the strategic imperatives. Paper presented at the 37th Annual Hawaii International Conference on System Sciences, Hawaii, USA, January 5-8, 2004. http://dx.doi.org/10.1109/HICSS.2004.1265560.

[17] S. Corcoran, Introducing "Social Maturity": How Social Media Transforms Companies. Retrieved on January 21, 2016, from http://blogs.forrester.com/sean_corcoran/11-06-02-introducing_social_ maturity_how_social_media_transforms_companies/ 
[18] J. Jussila, H. Kärkkäinen, and J. Lyytikkä, Towards maturity modeling approach for social media adoption in innovation. Proceedings of the 4th ISPIM Innovation Symposium (p1-14). Manchester: International Society for Professional Innovation Management ISPIM, 2011.

[19] A. Luxemburg, and K. Zwiggelaar, What is a mature organization in social media use? Commenting on the Social Media Maturity Model (S3M). XR Magazine, p22-26, 2011.

[20] A. M. Duane, and P. O'Reilly, A conceptual stages of growth model for managing an organization's social media business profile (SMBP). Paper presented at the 33rd International Conference on Information Systems, Orlando, Florida, USA, December 16-19, 2012.

[21] O. Levina, and I. Vilnai-Yavetz, E-visibility maturity model: A tool for assessment and comparison of individual firms and sets of firms in e-business. Electronic Commerce Research and Applications, 14(6), p480-498, 2015. http://dx.doi.org/10.1016/j.elerap.2015.07.004.

[22] T. P. Liang, and E. Turban, Introduction to the special issue social Commerce: A research framework for social commerce. International Journal of Electronic Commerce, 16(2), p5-14, 2011. http://dx.doi.org/10.2753/jec1086-4415160201.

[23] E. M. Rogers, Diffusion of Innovations (5th Ed.). New York: Free Press, 2003.

[24] A. Q. Chung, P. Andreev, M. Benyoucef, A. Duane, and P. O'Reilly, Managing an organisation's social media presence: An empirical stages of growth model. International Journal of Information Management, 37(1), p1405-1417, 2017. http://dx.doi.org/10.1016/j.ijinfomgt.2016.10.003.

[25] Axelos, ITIL maturity model. Retrieved on January 21, 2016, from https://www.axelos.com/Corporate/media/Files/Misc\%20Qualification $\% 20$ Docs/ITIL-Maturity-Model.pdf.

[26] ISACA, COBIT 5: A business framework for the governance and management of enterprise IT. Retrieved on January 21, 2016, from https://cobitonline.isaca.org/l3-main?book=framework\&hl=Cobit $\% 204$ .1\#framework-chapter08-section02-figure01. 
[27] G. V. D. Sleen, E-Business maturity model 2.0. Retrieved on January 21, 2016, from http://www.slideshare.net/gvdsleen/e-business-maturity-model-20.

[28] M. J. Earl, Evolving the e-business. Business Strategy Review, 11(2), p33-38, 2000. http://dx.doi.org/10.1111/1467-8616.00135.

[29] J. F. Rayport, and B. J. Jaworski, Introduction to e-commerce. Boston, MA: McGraw-Hill/Irwin marketspaceU, 2002.

[30] P. Fraser, J. Moultrie, and M. Gregory, The use of maturity models/grids as a tool in assessing product development capability. Paper presented at the IEEE International Engineering Management Conference, Cambridge, UK, August 18-20, 2002. http://dx.doi.org/10.1109/IEMC.2002.1038431.

[31] R. D. Galliers, and A. Sutherland, Information systems management and strategy formulation: the 'stages of growth' model revisited. Information Systems Journal, 1(2), p89-114, 1991. http://dx.doi.org/10.1111/j.1365-2575.1991.tb00030.x.

[32] T. Lehmkuhl, U. Baumöl, and R. Jung, Towards a maturity model for the adoption of social media as a means of organizational innovation. Paper presented at the 2013 46th Hawaii International Conference on System Sciences, Hawaii, USA, January 7-10, 2013. http://dx.doi.org/10.1109/HICSS.2013.561.

[33] J. M. Camiade, and M. Claisse, The maturity model social media marketing. Retrieved on January 21, 2016, from http://www.atinternet.com/uploads/AT_social-maturity-model_en.pdf.

[34] K. Laosethakul, and W. Boulton, Critical success factors for e-commerce in Thailand: Cultural and infrastructural influences. The Electronic Journal of Information Systems in Developing Countries, $30(2)$, p1-22, 2007. http://www.ejisdc.org/Ojs2/index.php/ejisdc/article/view/389.

[35] C. Wang, and P. Zhang, The evolution of social commerce: The people, management, technology, and information dimensions. Communications of the Association for Information Systems, 31(5), p1-23, 2012. http://aisel.aisnet.org/cais/vol31/iss1/5. 
[36] R. K. Yin, Case study research: design and methods. Beverly Hills, CA: Sage Publications, 1984.

[37] O. Willner, J. Gosling, and P. Schönsleben, Establishing a maturity model for design automation in sales-delivery processes of ETO products. Computers in Industry, 82(C), p57-68, 2016. http://dx.doi.org/10.1016/j.compind.2016.05.003.

[38] M. Kerrigan, A capability maturity model for digital investigations. Digital Investigation, 10(1), p19-33, 2013. http://dx.doi.org/10.1016/j.diin.2013.02.005.

[39] B. Curtis, B. Hefley, and S. Miller, People capability maturity model $(P-C M M)$ version 2.0. Retrieved on January 21, 2016, from https://www.sei.cmu.edu/reports/09tr003.pdf.

[40] M. Gill, and S. VanBoskirk, The digital maturity model 4.0 benchmarks: digital business transformation playbook. Retrieved on January 21, 2016, from https://forrester.nitro-digital.com/pdf/Forrester-s\%20Digital\%20Maturi ty\%20Model\%204.0.pdf.

[41] NIST, 2015-2016 Baldrige excellence framework. Retrieved on January 21 , 2016 , from https://www.alamo.edu/uploadedFiles/District/About_Us/Chancellor/2 015-2016_Baldrige_Excellence_Framework_Business_Nonprofit.pdf.

[42] A. Heller, and J. Varney, Using process management maturity models: a path to attaining process management excellence. Retrieved on January 21, 2016, from http://kb.acodev.be/fr/system/files/node/284/using_process_manageme nt_maturity_models.pdf.

[43] I. Mergel, A framework for interpreting social media interactions in the public sector. Government Information Quarterly, 30(4), p327-334, 2013. http://dx.doi.org/10.1016/j.giq.2013.05.015.

[44] E. Constantinides, C. L. Romero, and M. A. G. Boria, Social media: a new frontier for retailers? In B. Swoboda, D. Morschett, T. Rudolph, P. Schnedlitz, and H. Schramm-Klein (Eds.), European Retail Research (p1-28). Springer, 2009. http://dx.doi.org/10.1007/978-3-8349-8099-1_1. 
[45] C. W. Choo, Information culture and organizational effectiveness. International Journal of Information Management, 33(5), p775-779, 2013. http://dx.doi.org/10.1016/j.ijinfomgt.2013.05.009.

[46] S. Kamal, S. C. Chu, and M. Pedram, Materialism, attitudes: and social media usage and their impact on purchase intention of luxury fashion goods among American and Arab young generations. Journal of Interactive Advertising, 13(1), p27-40, 2013. http://dx.doi.org/10.1080/15252019.2013.768052.

[47] C. S. P. Ng, Intention to purchase on social commerce websites across cultures: A cross-regional study. Information \& Management, 50(8), p609-620, 2013. http://dx.doi.org/10.1016/j.im.2013.08.002.

[48] C. Li, and J. Bernoff, Groundswell: Winning in a World Transformed by Social Technologies. Harvard Business Review Press, 2008.

[49] L. Patterson, Managing Touch Point Value: 10 Steps to Improve Customer Engagement. Retrieved on February 21, 2016, from https://www.visionedgemarketing.com/images/articles/managing\%20to uch $\% 20$ point $\% 20$ value $\% 2010 \% 20$ steps $\% 20$ to $\% 20$ improve $\% 20$ custom er\%20engagement.pdf. 